\title{
Effects of Saccharomyces cerevisiae Addition in Dairy Cows Diets
}

\author{
Marinela ENCULESCU
}

Research and Development Institute for Bovine, Șoseaua București-Ploiești, km 21, Balotești, 077015, Romania

Corresponding author: M. Enculescu e-mail: marinelaenculescu2006@yahoo.com

\section{RESEARCH ARTICLE}

\begin{abstract}
The aim of this study was to evaluate the effects of fresh yeast (Saccharomyces cerevisiae) supplementation in the dairy cows' diets on productive performances and health status. The study was carried out in the experimental farm of the Research and Development Institute for Bovine Balotești on 50 multiparous Romanian Black and Spotted dairy cows, randomly divided into two groups ( $N=25$ heads/group), according to age, milk yield, body weight and health status. The experimental group received $80 \mathrm{~g}$ Saccharomyces cerevisiae/head/day for one year. The groups were fed with the same diet and had free access to water and salt. Results were expressed as a mean ( \pm Standard Deviation). The t-test was applied to obtain the significance of difference. Supplementation of the diet with Saccharomyces cerevisiae had a significant effect $(\mathrm{P}<0.001)$ on milk yield $(20.71 \pm 1.65 \mathrm{l} / \mathrm{head} / \mathrm{day})$ for the experimental group comparing with the control group (18.22 $\pm 1.81 \mathrm{l} / \mathrm{head} /$ day), and on milk protein and lactose $(\mathrm{P}<0.05)$. The addition of Saccharomyces cerevisiae in dairy cows' diet did not improve the milk fat, hematological and biochemical/urine indicators in the experimental group $(\mathrm{P}>0.05)$. However, for alkaline phosphatase, differences at the end of the study have been observed $(\mathrm{P}<0.01)$. The beneficial effect of the yeast and yeast products in ruminants could be attributed to microbial activity by increasing the number of beneficial bacteria in the rumen of the animals. The use of Saccharomyces cerevisiae as an alternative source of economic protein, vitamins and minerals in dairy cows' diet represents an effective measure to optimize animal productivity.
\end{abstract}

Keywords: dairy cows; animal nutrition; animal health; cattle productivity; Saccharomyces cerevisiae.

Received: 22 September 2020 Accepted: 10 February 2021 Published: 15 May 2021

DOI:

10.15835/buasvmcn-asb:2020.0022

2021 Authors. The papers published in this journal are licensed under the Creative Commons AttributionNonCommercial-NoDerivatives 4.0 International License

\section{INTRODUCTION}

Saccharomyces cerevisiae (SC) has been used as a supplement in ruminants to improve milk yield and milk composition of the animals (Maamouri et al., 2014; Bakr et al., 2015). Saccharomyces cerevisiae through its high protein content, amino acids, minerals and vitamins, represents a valuable ingredient that can be used in feeding dairy cows in order to optimize the diet's structure. The actions of yeast products are generally considered to involve changes in rumen fermentation rates (Chaucheyras-Durand et al., 2008; Uyeno et al., 2015). The balance in rumen microbial flora plays an important role in feed utilization, with positive results in productivity (Santra and Karim, 2003). Saccharomyces cerevisiae can improve the microbial activity by increasing the number of beneficial bacteria (cellulolytic, amylolytic, proteolytic) and protozoa (El-Ghani, 2004) in the rumen of the animals (Mosoni et al., 2007; Guedes et al., 2008), improving overall performance response of dairy cows (Sniffen et al., 2007). Another function of yeast is the consumption of oxygen, which creates an anaerobic environment required by ruminal microorganisms (Dehority, 2003). The rumen microbial profile depends on the type of feed (Shakira et al., 2015) that is digested by microbial biomass, which helps in better metabolism (Carberry et 
al., 2012). The feed microbial flora could be managed by using beneficial microbial supplementation, such as yeasts. The aim of this study was to evaluate the effect of Saccharomyces cerevisiae supplementation in the dairy cow's diet on productive performances and health status.

\section{MATERIALS AND METHODS}

The study was carried out at the Experimental Farm of the Research and Development Institute for Bovine Balotești $\left(44^{\circ} 36^{\prime} 46^{\prime \prime} \mathrm{N} 26^{\circ} 4^{\prime} 43^{\prime \prime} \mathrm{E}\right)$, Romania, in accordance with the Romanian Law no. 43/2014 and the Council Directive $2010 / 63 / E U$ on the protection and handling of animals used for scientific purposes. The trial was designed as randomized blocks. The 50 multiparous Romanian Black and Spotted dairy cows, clinically healthy, were randomly divided into two groups: experimental group and control group ( $\mathrm{N}=25$ heads/group), according to age (5-8 years old), milk yield (18.5 kg/head/day), and body weight (550-580 live weight). The experimental group received $80 \mathrm{~g}$ Saccharomyces cerevisiae/head/day for one year (January 2019-December 2019). The cows were housed under tied stanchion barn conditions.

Feeding system was differentiated by season, in the winter season, the diet consisted of $5 \mathrm{~kg}$ alfalfa hay, $25 \mathrm{~kg}$ corn silage, $4 \mathrm{~kg}$ concentrates, and during summer, the diet consisted of $40 \mathrm{~kg}$ green grass, $4 \mathrm{~kg}$ alfalfa hay, and $4 \mathrm{~kg}$ concentrates. The lactating dairy cows received salt and water ad libitum.

The chemical composition of the studied fodder was performed using Weende scheme. The nutritive crude value (Table 1) of the feeds used in the dairy cows feeding was determined on the basis of the obtained raw chemical composition and of some established regression equations (Burlacu, 1998 cited by Stoica and Stoica, 2001). The diets used in lactating dairy cows by season are presented in Table 2 and Table 3.

Table 1. The nutritional value of the analyzed fooders ( $\mathrm{g} / \mathrm{kg}$ forage)

\begin{tabular}{|l|l|l|l|l|l|l|}
\hline Nutritive crude value & DM (kg) & MNU/kg & DIPN (g) & DIPE (g) & Ca (g) & P (g) \\
\hline Alfalfa hay & 0.87 & 0.64 & 93 & 75 & 10 & 1.9 \\
\hline Corn silage & 0.28 & 0.20 & 13.52 & 19.68 & 1.10 & 0.50 \\
\hline Concentrates & 0.90 & 0.99 & 123.5 & 85 & 9.6 & 6.9 \\
\hline Green grass & 0.23 & 0.21 & 22 & 20 & 1.3 & 0.7 \\
\hline Fresh yeast (SC) & 0.90 & 1.20 & 323 & 186 & 2.6 & 20 \\
\hline
\end{tabular}

* Note: DM = dry matter; MNU = milk nutrition units; DIPN = digestible intestine protein allowed by the nitrogen content of the fodder; DIPE = digestible intestine protein allowed by the energy content of the fodder; $\mathrm{Ca}=$ calcium; $\mathrm{P}=$ phosphorus.

Table 2. The diet used in lactating dairy cows feeding in winter season

\begin{tabular}{|l|l|l|l|l|l|l|l|}
\hline \multirow{2}{*}{ Fodder } & \multirow{2}{*}{ Kg } & \multicolumn{7}{|c|}{ Standard norms } \\
\cline { 3 - 9 } & & $\mathbf{1 5 - 1 8}$ & $\mathbf{1 3 - 1 5}$ & $\mathbf{1 2 0 0 - 1 3 0 0}$ & $\mathbf{1 2 0 0 - 1 3 0 0}$ & $\mathbf{9 0}$ & $\mathbf{5 4 - 6 0}$ \\
\cline { 3 - 9 } & & $\mathbf{D M}(\mathbf{k g})$ & MNU (kg) & DIPN (g) & DIPE (g) & Ca (g) & P (g) \\
\hline Alfalfa hay & 5 & 4.35 & 3.20 & 465 & 375 & 50.0 & 9.50 \\
\hline Corn silage & 25 & 7 & 5 & 338 & 492 & 27.50 & 12.50 \\
\hline Basic ratio input & 30 & 11.35 & 8.20 & 803 & 867.00 & 77.50 & 22.00 \\
\hline Concentrates & 4.0 & 3.60 & 3.97 & 494 & 340 & 38.40 & 27.60 \\
\hline Total ensured (Groups C + E) & 34 & 14.95 & 12.17 & 1279 & 1207 & 115.90 & 49.60 \\
\hline Fresh yeast (SC) & 0.08 & 0.07 & 0.10 & 25.84 & 14.88 & 0.21 & 1.6 \\
\hline Total ensured (Group E) & 34.08 & 15.02 & 12.27 & 1322.84 & 1221.88 & 116.11 & 51.20 \\
\hline
\end{tabular}

* Note: $\mathrm{E}=$ experimental group ( $80 \mathrm{~g}$ SC/head/day); $\mathrm{C}=$ control group; $\mathrm{DM}=$ dry mater; $\mathrm{MNU}=$ milk nutrition units; DIPN = digestible intestine protein allowed by the nitrogen content of the fodder; DIPE = digestible intestine protein allowed by the energy content of the fodder; $\mathrm{Ca}=$ calcium; $\mathrm{P}=$ phosphorus. 
Table 3. The diet used in lactating dairy cows feeding in summer season

\begin{tabular}{|l|l|l|l|l|l|l|l|}
\hline \multirow{2}{*}{ Fodder } & \multirow{2}{*}{ Kg } & \multicolumn{7}{|c|}{ Standard norms } \\
\cline { 3 - 8 } & & $\mathbf{1 5 - 1 7}$ & $\mathbf{1 3 - 1 5}$ & $\mathbf{1 2 0 0 - 1 3 0 0}$ & $\mathbf{1 2 0 0 - 1 3 0 0}$ & $\mathbf{9 0}$ & $\mathbf{5 4 - 6 0}$ \\
\cline { 3 - 8 } & & $\mathbf{D M}(\mathbf{k g})$ & $\mathbf{M N U}(\mathbf{k g})$ & $\mathbf{D I P N}(\mathbf{g})$ & DIPE (g) & Ca (g) & P (g) \\
\hline Green grass & 40 & 9.2 & 8.4 & 880 & 800 & 52 & 28 \\
\hline Alfalfa hay & 4 & 3.48 & 2.56 & 372 & 300 & 40 & 7.60 \\
\hline Basic ratio input & 44 & 12.68 & 10.96 & 1252 & 1100 & 92.00 & 35.60 \\
\hline Concentrates & 4.0 & 3.60 & 3.97 & 494 & 340 & 38.40 & 27.60 \\
\hline Total ensured (Groups C + E) & 48 & 16.28 & 14.93 & 1746.00 & 1440 & 130.40 & 63.20 \\
\hline Fresh yeast (SC) & 0.08 & 0.07 & 0.10 & 25.84 & 14.88 & 0.21 & 1.6 \\
\hline Total ensured (Group E) & 48.08 & 16.35 & 15.03 & 1771.84 & 1454.88 & 130.61 & 64.80 \\
\hline
\end{tabular}

* Note: $\mathrm{E}=$ experimental group (80g SC/head/day); $\mathrm{C}=$ control group; DM = dry matter; $\mathrm{MNU}=$ milk nutrition units; DIPN = digestible intestine protein allowed by the nitrogen content of the fodder; DIPE = digestible intestine protein allowed by the energy content of the fodder; $\mathrm{Ca}=$ calcium; $\mathrm{P}=$ phosphorus

Milk yield and milk quality indicators (fat, protein, lactose), were monitored monthly for both groups. Cows were fed as a total mixed ratio (TMR) and milked twice daily. Milk samples (30 ml) were collected during morning and evening milkings before feeding and kept at $4^{\circ} \mathrm{C}$ for analysis. The blood/urinary samples were evaluated at following intervals: January (start), May (mid) and December (final) for both groups. For the haematological examinations, blood samples (1-2 ml) were collected aseptically from the jugular vein of each animal, 2-4 hours after the morning feeding, in vacutainer tubes with disodium-ethylene diamine tetraacetic acid (EDTA/Na2). After harvesting, the samples were chilled to $+4^{\circ} \mathrm{C}$. For the serum biochemical parameters, blood samples were collected aseptically from the jugular vein $(9 \mathrm{ml})$, in vacutainers without anticoagulant for serum separation by centrifugation at $3000 \mathrm{rpm}$ for $15 \mathrm{~min}$ and stored in aliquots at $-20^{\circ} \mathrm{C}$ till further analysis. Urine samples were collected in $50 \mathrm{ml}$ sterilized vials, as free catch during micturition, from both studied groups. Haematological parameters (red blood cells, hemoglobin, hematocrit, total white blood cells, lymphocytes, neutrophil) were determined using automated hematology analyzer Abacus Junior Vet 5 (Diatron, Hungary). The serum biochemical profile (total proteins, albumin, urea, glucose, total cholesterol, alkaline phosphatase, asparagine aminotransferase, alanine aminotransferase, total calcium, inorganic phosphorus, magnesium) was analyzed using a semiautomated biochemical analyzer StarDust MC 15 (DiaSys Diagnostics Systems Gmbh, Germany) and DiaSys reagents in dedicated kits. Urine examination (bilirubin, urobilinogen, ketones, ascorbic acid, glucose, protein, blood, $\mathrm{pH}$, nitrites, leukocytes, specific gravity) was determined with the DocUReader urine analyzer (Hungary). The milk quality indicators were evaluated using the Ekomilk 120 ultrasonic analyzer (Bulgaria). The analyses were carried out in the Animal Physiology and Biochemistry Laboratory of the institute.

Results were expressed as a mean $( \pm$ Standard Deviation) and compared by applying t-test using a descriptive statistical tool (computer software Microsoft Excel).

The statistical model was:

Yij $=\mu+\mathrm{Ti}+$ eij, where: $\mu=$ overall mean; $\mathrm{Ti}=$ fixed effect of $\operatorname{diet}(\mathrm{i}=1,2)$ and eij $=$ residual error term.

The differences between mean values of the treatments were considered significant at $P<0.05$ and $P<0.01$.

\section{RESULTS AND DISCUSSIONS}

The studied animals had an average daily consumption (depending on the season and the treatments), between 14.95-16.35 kg DM/animal/day, 12.17-15.03 UNL, 1279.00-1771.84 g PDIN, 1207.00-1454.88 g PDIE, 115.90$130.61 \mathrm{~g} \mathrm{Ca}$, and 49.60-64.80 g P, values that fall within the standard norms in relation to body weight and milk production (Table 4).

Table 4. The average daily consumption of the dairy cows on seasons

\begin{tabular}{|l|l|l|l|l|l|l|}
\hline Season/Group & DM (kg) & UNL & PDIN (g) & PDIE (g) & \multicolumn{1}{l|}{ Ca (g) } & P (g) \\
\hline Winter season & 15.02 & 12.27 & 1322.84 & 1221.88 & 116.11 & 51.20 \\
\hline E (SC) & 14.95 & 12.17 & 1279 & 1207 & 115.90 & 49.60 \\
\hline C & 16.35 & 15.03 & 1771.84 & 1454.88 & 130.61 & 64.80 \\
\hline Summer season & 16.28 & 14.93 & 1746 & 1440 & 130.40 & 63.20 \\
\hline E (SC) &
\end{tabular}

Note: $\mathrm{E}=$ experimental group (80g SC/head/day); $\mathrm{C}=$ control group; $\mathrm{DM}=$ dry matter; UNL = milk nutrition units; $\mathrm{PDIN}=$ digestible intestine protein allowed by the nitrogen content of the fodder; PDIE = digestible intestine protein allowed by the energy content of the fodder; $\mathrm{Ca}=$ calcium; $\mathrm{P}=$ phosphorus. 
Supplementation of the diet with Saccharomyces cerevisiae had a significant effect $(\mathrm{P}<0.01)$ on milk yield for the experimental group (E) compared to the control group (C), starting with the $2^{\text {nd }}$ and $4^{\text {th }}$ months of administration, respectively (Table 5).

However, in the following months there was a progressive increase in milk yield for the experimental group (E) compared to the control group $(C)$, but with no statistical significance $(P>0.05)$. At the end of the experimental period, an average milk production higher with $2.49 \mathrm{l} / \mathrm{head} /$ day was obtained for the experimental group compared to the control group $(\mathrm{P}<0.001)$.

Table 5. Milk yield in lactating dairy cows

\begin{tabular}{|c|c|c|}
\hline \multirow{3}{*}{$\begin{array}{l}\text { Parameters/ } \\
\text { month }\end{array}$} & \multicolumn{2}{|l|}{ Treatments } \\
\hline & $\mathrm{E}(\mathrm{SC})$ & $\mathrm{C}$ \\
\hline & $\mathrm{X} \pm \mathrm{SD}$ & $\mathrm{X} \pm \mathrm{SD}$ \\
\hline \multicolumn{3}{|c|}{ Milk yield, l/day } \\
\hline January & $18.87 \pm 1.67$ & $18.68 \pm 1.83$ \\
\hline February & $18.55 \pm 1.58^{* *}$ & $17.15 \pm 1.24$ \\
\hline March & $20.88 \pm 1.96$ & $21.48 \pm 2.15$ \\
\hline April & $19.15 \pm 2.03^{* *}$ & $17.22 \pm 1.98$ \\
\hline May & $19.48 \pm 2.29$ & $18.94 \pm 2.45$ \\
\hline June & $18.52 \pm 1.54$ & $17.53 \pm 1.68$ \\
\hline July & $19.28 \pm 2.09$ & $18.85 \pm 2.12$ \\
\hline August & $19.59 \pm 1.93$ & $18.87 \pm 2.11$ \\
\hline September & $18.73 \pm 1.53$ & $17.85 \pm 1.81$ \\
\hline October & $20.43 \pm 1.68^{*}$ & $19.26 \pm 1.92$ \\
\hline November & $20.19 \pm 1.27$ & $19.58 \pm 1.22$ \\
\hline December & $20.71 \pm 1.65^{* * *}$ & $18.22 \pm 1.81$ \\
\hline
\end{tabular}

Note: $\mathrm{E}=$ experimental group (80g SC/head/day); $\mathrm{C}=$ control group; Milk yield - February: ${ }^{* *} \mathrm{P}=0.0011, \mathrm{P}<0.01 ;$ April: ${ }^{* *} \mathrm{P}=0.0014$, $\mathrm{P}<0.01$; October: ${ }^{*} \mathrm{P}=0.0114, \mathrm{P}<0.05$; December: ${ }^{* *} \mathrm{P}=0.00041, \mathrm{P}<0.001$.

A significant improvement $(\mathrm{P}<0.05)$ was found in the milk protein and milk lactose after 12 months of Saccharomyces cerevisiae administration (Table 6), while the milk fat was not influenced by the yeast supplementation $(\mathrm{P}>0.05)$. Our results are in accordance with those reported in the literature, for instance Bitencourt et al. (2011) showed that supplementation of lactating cows feed with viable cells of Saccharomyces cerevisiae increased the daily yield of protein and lactose in mid-lactation dairy cows. Other authors reported only a minor improvement in milk production (Bakr et al., 2015; Zhu et al., 2017) or found no effect of yeast on milk production (Cooke et al., 2007).

A linear trend of increasing milk yield and milk fat in response to supplementation with Saccharomyces cerevisiae (increased milk yield by $1.18 \mathrm{~kg} /$ day, fat-corrected milk by $1.61 \mathrm{~kg} /$ day), has been reported by Poppy et al. (2012). In contrast, Hristov et al. (2010) did not find any positive effect of using yeast in the Holstein cows diet. Responses to the addition of the yeast to dairy cows vary depending on the breed, diet, the type and dose of yeast used, the physiological status of the animals, the stage of lactation and the environmental conditions.

Table 6. Milk fat, protein and lactose in lactating dairy cows

\begin{tabular}{|l|l|l|}
\hline \multirow{2}{*}{$\begin{array}{l}\text { Parameters/ } \\
\text { month }\end{array}$} & Treatments & C \\
\cline { 2 - 3 } & E (SC) & X \pm SD \\
\cline { 2 - 3 } & X \pm SD & $4.17 \pm 0.50$ \\
\hline \multicolumn{2}{|c|}{ Fat, \% } & $4.19 \pm 0.59$ \\
\hline January (start) & $4.15 \pm 0.48$ & $4.11 \pm 0.42$ \\
\hline February & $4.23 \pm 0.42$ & $4.14 \pm 0.73$ \\
\hline March & $4.19 \pm 0.46$ & $4.22 \pm 0.52$ \\
\hline April & $4.08 \pm 0.63$ & $3.81 \pm 0.82$ \\
\hline May & $4.24 \pm 0.55$ & $3.92 \pm 0.46$ \\
\hline June & $3.99 \pm 0.79$ & $4.01 \pm 0.78$ \\
\hline July & $4.04 \pm 0.52$ & \\
\hline August & $3.95 \pm 0.49$ & \\
\hline
\end{tabular}




\begin{tabular}{|c|c|c|}
\hline September & $4.21 \pm 0.58$ & $4.11 \pm 0.61$ \\
\hline October & $4.30 \pm 0.39$ & $4.25 \pm 0.42$ \\
\hline November & $4.24 \pm 0.46$ & $4.03 \pm 0.49$ \\
\hline December (final) & $4.32 \pm 0.27$ & $4.17 \pm 0.31$ \\
\hline \multicolumn{3}{|c|}{ Protein, \% } \\
\hline January (start) & $3.17 \pm 0.30$ & $3.12 \pm 0.24$ \\
\hline February & $3.21 \pm 0.14$ & $3.16 \pm 0.12$ \\
\hline March & $3.27 \pm 0.20$ & $3.22 \pm 0.23$ \\
\hline April & $3.31 \pm 0.36$ & $3.30 \pm 0.27$ \\
\hline May & $3.22 \pm 0.31$ & $3.14 \pm 0.23$ \\
\hline June & $3.29 \pm 0.19$ & $3.26 \pm 0.18$ \\
\hline July & $3.42 \pm 0.19$ & $3.39 \pm 0.22$ \\
\hline August & $3.29 \pm 0.19$ & $3.21 \pm 0.15$ \\
\hline September & $3.31 \pm 0.23$ & $3.34 \pm 0.19$ \\
\hline October & $3.20 \pm 0.29$ & $3.18 \pm 0.28$ \\
\hline November & $3.30 \pm 0.21$ & $3.27 \pm 0.18$ \\
\hline December (final) & $3.46 \pm 0.23^{*}$ & $3.32 \pm 0.28$ \\
\hline \multicolumn{3}{|c|}{ Lactose, $\%$} \\
\hline January (start) & $4.45 \pm 0.24$ & $4.42 \pm 0.23$ \\
\hline February & $4.49 \pm 0.17$ & $4.51 \pm 0.14$ \\
\hline March & $4.39 \pm 0.16$ & $4.36 \pm 0.18$ \\
\hline April & $4.35 \pm 0.21$ & $4.34 \pm 0.11$ \\
\hline May & $4.54 \pm 0.12$ & $4.50 \pm 0.16$ \\
\hline June & $4.55 \pm 0.24$ & $4.43 \pm 0.16$ \\
\hline July & $4.42 \pm 0.12$ & $4.39 \pm 0.15$ \\
\hline August & $4.49 \pm 0.17$ & $4.41 \pm 0.18$ \\
\hline September & $4.51 \pm 0.19$ & $4.47 \pm 0.20$ \\
\hline October & $4.52 \pm 0.18$ & $4.49 \pm 0.21$ \\
\hline November & $4.47 \pm 0.17^{*}$ & $4.38 \pm 0.15$ \\
\hline December (final) & $4.58 \pm 0.19^{*}$ & $4.48 \pm 0.17$ \\
\hline
\end{tabular}

Note: $\mathrm{E}=$ experimental group $\left(80 \mathrm{~g} \mathrm{SC} /\right.$ head/day); $\mathrm{C}=$ control group; Protein: December: ${ }^{*} \mathrm{P}=0.0593, \mathrm{P}<0.05$; Lactose: November: ${ }^{*} \mathrm{P}$ $=0.0529, \mathrm{P}<0.05$; December: ${ }^{*} \mathrm{P}=0.0557, \mathrm{P}<0.05$.

Moreover, an important aspect was to evaluate the effects of Saccharomyces cerevisiae addition in the diets on the health status of cows. The obtained haematological values (Table 7) were within physiological limits of the main haematological constants (erythrocytes, hemoglobin, leukocytes) in both groups studied, with few exceptions, hematocrit concentration and lymphocytes percentage, respectively.

Table 7. Hematological parameters in lactating dairy cows

\begin{tabular}{|c|c|c|c|}
\hline \multirow{3}{*}{$\begin{array}{l}\text { Parameters/ } \\
\text { month }\end{array}$} & \multicolumn{2}{|l|}{ Treatments } & \multirow{3}{*}{ Reference limits } \\
\hline & E (SC) & C & \\
\hline & $\mathrm{X} \pm \mathrm{SD}$ & $\mathrm{X} \pm \mathrm{SD}$ & \\
\hline \multicolumn{3}{|l|}{$\mathrm{RBC}, 10^{6} / \mu \mathrm{L}$} & \multirow{4}{*}{$5-8$} \\
\hline January (start) & $6.59 \pm 0.59$ & $6.57 \pm 0.51$ & \\
\hline May & $6.33 \pm 0.68$ & $6.39 \pm 0.65$ & \\
\hline December (final) & $6.54 \pm 0.58$ & $6.71 \pm 0.47$ & \\
\hline \multicolumn{3}{|l|}{$\mathrm{HGB}, \mathrm{g} / \mathrm{dL}$} & \multirow{4}{*}{$9-11$} \\
\hline January (start) & $10.12 \pm 0.80$ & $9.85 \pm 0.81$ & \\
\hline May & $9.00 \pm 0.81$ & $9.01 \pm 0.72$ & \\
\hline December (final) & $9.80 \pm 0.64$ & $9.27 \pm 0.62$ & \\
\hline \multicolumn{3}{|l|}{ HCT, \% } & \multirow{4}{*}{$32-38$} \\
\hline January (start) & $28.36 \pm 2.58$ & $27.96 \pm 2.47$ & \\
\hline May & $27.95 \pm 2.80$ & $27.86 \pm 2.73$ & \\
\hline December (final) & $30.20 \pm 2.53$ & $29.05 \pm 1.78$ & \\
\hline \multicolumn{3}{|l|}{$\mathrm{WBC}, 10^{3} / \mu \mathrm{L}$} & $6.5-9.5$ \\
\hline
\end{tabular}




\begin{tabular}{|c|c|c|c|}
\hline January (start) & $9.33 \pm 1.73$ & $8.44 \pm 2.35$ & \\
\hline May & $9.07 \pm 2.42$ & $8.81 \pm 1.69$ & \\
\hline December (final) & $8.55 \pm 1.09$ & $8.76 \pm 1.78$ & \\
\hline \multicolumn{3}{|l|}{$\mathrm{LY}, \%$} & \multirow{4}{*}{$45-61$} \\
\hline January (start) & $69.48 \pm 11.70$ & $65.63 \pm 10.14$ & \\
\hline May & $52.98 \pm 10.42$ & $53.79 \pm 11.91$ & \\
\hline December (final) & $53.40 \pm 8.99$ & $53.74 \pm 10.24$ & \\
\hline \multicolumn{3}{|l|}{ NE, \% } & \multirow{4}{*}{$15-41$} \\
\hline anuary (start) & $22.74 \pm 10.51$ & $26.06 \pm 9.27$ & \\
\hline May & $41.75 \pm 11.09$ & $42.05 \pm 12.32$ & \\
\hline December (final) & $36.46 \pm 12.70$ & $36.14 \pm 11.65$ & \\
\hline
\end{tabular}

Note: $\mathrm{E}=$ experimental group $(80 \mathrm{~g} \mathrm{SC} /$ head/day); $\mathrm{C}=$ control group. $\mathrm{RBC}=$ red blood cells, $\mathrm{HGB}=$ hemoglobin, $\mathrm{HCT}=$ hematocrit, WBC $=$ total white blood cells, $\mathrm{LY}=$ lymphocytes, $\mathrm{NE}=$ neutrophils. Limits according to laboratory standards Abacus Junior vet 5 : haematological control 5pDiff normal values.

Protein profile parameters (total protein, albumin and urea), and energy profile (glucose and cholesterol), showed fluctuating variations (Table 8) for glucose, total protein, albumin and urea, without being influenced by the addition of yeast $(\mathrm{P}>0.05)$.

Table 8. Protein and energy profiles in lactating dairy cows

\begin{tabular}{|c|c|c|c|}
\hline \multirow{3}{*}{$\begin{array}{l}\text { Parameters/ } \\
\text { month }\end{array}$} & \multicolumn{2}{|l|}{ Treatments } & \multirow{3}{*}{ Reference limits } \\
\hline & E (SC) & C & \\
\hline & $\mathrm{X} \pm \mathrm{SD}$ & $\mathrm{X} \pm \mathrm{SD}$ & \\
\hline \multicolumn{3}{|c|}{ Proteins, mg/dl } & \multirow{4}{*}{$6.8-8.4$} \\
\hline January (start) & $7.62 \pm 0.40$ & $7.80 \pm 0.61$ & \\
\hline May & $7.98 \pm 0.72$ & $7.78 \pm 0.53$ & \\
\hline December (final) & $8.20 \pm 0.38$ & $7.70 \pm 0.37$ & \\
\hline \multicolumn{3}{|c|}{ Albumin, g/dl } & \multirow{4}{*}{$2.9-3.8$} \\
\hline January (start) & $3.42 \pm 1.49$ & $3.7 \pm 1.40$ & \\
\hline May & $3.5 \pm 1.39$ & $3.34 \pm 1.35$ & \\
\hline December (final) & $3.61 \pm 1.21$ & $3.52 \pm 1.46$ & \\
\hline \multicolumn{3}{|c|}{ Urea, mg/dl } & \multirow{4}{*}{$20-40$} \\
\hline January (start) & $36.32 \pm 19.96$ & $37.44 \pm 19.56$ & \\
\hline May & $36.96 \pm 19.68$ & $37.76 \pm 19.70$ & \\
\hline December (final) & $38.84 \pm 5.47$ & $36.2 \pm 6.78$ & \\
\hline \multicolumn{3}{|c|}{ Glucose, $\mathrm{mg} / \mathrm{dl}$} & \multirow{4}{*}{$48-72$} \\
\hline January (start) & $51.46 \pm 5.41$ & $52.61 \pm 6.21$ & \\
\hline May & $53.38 \pm 6.07$ & $54.53 \pm 7.13$ & \\
\hline December (final) & $54.15 \pm 7.14$ & $55.64 \pm 9.33$ & \\
\hline \multicolumn{3}{|c|}{ Cholesterol, mg/dl } & \multirow{4}{*}{$124-224$} \\
\hline January (start) & $246.88 \pm 213.92$ & $250.88 \pm 213.47$ & \\
\hline May & $194.68 \pm 85.00$ & $202.68 \pm 78.48$ & \\
\hline December (final) & $199.12 \pm 50.86$ & $215.92 \pm 52.16$ & \\
\hline
\end{tabular}

Note: $\mathrm{E}=$ experimental group (80g SC/head/day); C = control group. Limits according to laboratory standards-Star Dust MC15: DiaSys control serum normal and pathological values.

Regarding the level of total cholesterol, the obtained average values were lower in the experimental group (E) compared to the control group (C), which could indicate a stimulation of free/unesterified fatty acid deposits/accumulations. Concerning the enzymatic profile, if the activity of the two transaminases (AST, ALT) was within the physiological limits in both groups, the alkaline phosphatase (ALP) activity exceeded the maximum limit recommended during the study (Table 9). 
Table 9. Enzime and mineral profiles in lactating dairy cows

\begin{tabular}{|c|c|c|c|}
\hline \multirow{3}{*}{$\begin{array}{l}\text { Parameters/ } \\
\text { month }\end{array}$} & \multicolumn{2}{|l|}{ Treatments } & \multirow{3}{*}{ Reference limits } \\
\hline & E (SC) & $\mathbf{C}$ & \\
\hline & $X \pm s d$ & $\mathrm{X} \pm \mathrm{sd}$ & \\
\hline \multicolumn{3}{|c|}{ AST, U/L } & \multirow{4}{*}{$21-43$} \\
\hline January (start) & $37.53 \pm 10.64$ & $39.5 \pm 11.01$ & \\
\hline May & $34.65 \pm 12.76$ & $40.11 \pm 10.38$ & \\
\hline December (final) & $38.72 \pm 10.91$ & $42.56 \pm 8.52$ & \\
\hline \multicolumn{3}{|c|}{ ALT, U/L } & \multirow{4}{*}{$<60$} \\
\hline January (start) & $30.73 \pm 18.49$ & $31.5 \pm 18.71$ & \\
\hline May & $38.80 \pm 19.14$ & $40.80 \pm 24.01$ & \\
\hline December (final) & $27.08 \pm 8.22$ & $28.32 \pm 11.12$ & \\
\hline \multicolumn{3}{|c|}{ ALP, U/L } & \multirow{4}{*}{$10-36$} \\
\hline January (start) & $67.48 \pm 17.57$ & $66.96 \pm 29.01$ & \\
\hline May & $50.96 \pm 25.09^{*}$ & $65.42 \pm 26.59$ & \\
\hline December (final) & $55.44 \pm 23.57^{*}$ & $71.80 \pm 21.08$ & \\
\hline \multicolumn{3}{|c|}{$\mathrm{Ca}, \mathrm{mg} / \mathrm{dl}$} & \multirow{4}{*}{$8-11$} \\
\hline January (start) & $8.56 \pm 0.65$ & $8.68 \pm 0.67$ & \\
\hline May & $8.8 \pm 0.72$ & $8.61 \pm 0.75$ & \\
\hline December (final) & $9.10 \pm 1.09$ & $8.57 \pm 0.66$ & \\
\hline \multicolumn{3}{|c|}{$\mathrm{P}, \mathrm{mg} / \mathrm{dl}$} & \multirow{4}{*}{$4.62-7$} \\
\hline January (start) & $4.35 \pm 0.75$ & $4.46 \pm 0.76$ & \\
\hline May & $4.47 \pm 0.76$ & $4.27 \pm 0.79$ & \\
\hline December (final) & $4.65 \pm 0.73$ & $4.43 \pm 0.80$ & \\
\hline \multicolumn{3}{|c|}{$\mathrm{Mg}, \mathrm{mg} / \mathrm{dl}$} & \multirow{4}{*}{$2.1-2.8$} \\
\hline January (start) & $2.38 \pm 0.30$ & $2.49 \pm 0.34$ & \\
\hline May & $2.50 \pm 0.48$ & $2.37 \pm 0.56$ & \\
\hline December (final) & $2.66 \pm 0.32$ & $2.45 \pm 0.30$ & \\
\hline
\end{tabular}

Note: $\mathrm{E}=$ experimental group $(80 \mathrm{~g} \mathrm{SC} /$ head $/$ day $) ; \mathrm{C}=$ control group. $\mathrm{AST}=$ asparagine aminotransferase, $\mathrm{ALT}=$ alanine aminotransferase, $\mathrm{ALP}=$ alkaline phosphatase, $\mathrm{Ca}=$ total calcium, $\mathrm{P}=$ inorganic phosphorus, $\mathrm{Mg}=$ magnesium. $\mathrm{ALP}: \mathrm{May} * \mathrm{P}=0.0210$, $\mathrm{P}<0.05$; December ${ }^{* *} \mathrm{P}=0.0128, \mathrm{P}<0.01$. Limits according to laboratory standards-Star Dust MC15:DiaSys control serum normal and pathological values.

After the 5th month and 12th month of yeast administration, the activity of this enzyme was lower in the experimental group ( $\mathrm{P}<0.05$ at 5 months; $\mathrm{P}<0.01$ at12 months), which suggests the involvement of the yeast in promoting intestinal metabolism and regenerating liver tissue. Regarding the mineral profile, in the first 5 months of the experimental period, the concentration of calcium in the blood was similar in both groups. After 12 months, the value of this index increased in the experimental group (E), as an effect of the yeast addition, without statistical significance $(\mathrm{P}>0.05)$. A similar pattern for the concentration of magnesium was observed. Also, the phosphoremia was higher in the experimental group (E) compared to the control group (C). This could be explained by the synergistic relationship between calcium and phosphorus, as a consequence of the common participation, first of all, in the constitution of the bone structure, as reported by Pârvu et al. (2003).

The results of the urinary examination of samples collected from the studied animals are presented in Table 10. Urine examination showed that all the studied parameters were within the normal physiological limits with minor fluctuations for urine proteins (30-100 mg/dl), being in agreement with the results reported by Zanetti et al. (2008).

Table 10. Urine parameters in lactating dairy cows

\begin{tabular}{|c|c|c|c|}
\hline \multirow{2}{*}{$\begin{array}{l}\text { Parameters/ } \\
\text { month }\end{array}$} & \multicolumn{2}{|c|}{ Treatments } & \multirow{2}{*}{ Reference limits } \\
\hline & E (SC) & C & \\
\hline \multicolumn{3}{|c|}{ Bilirubin, $\mathrm{mg} / \mathrm{dl}$} & \multirow{4}{*}{ Negative } \\
\hline January (start) & Negative & Negative & \\
\hline May & Negative & Negative & \\
\hline December (final) & Negative & Negative & \\
\hline \multicolumn{3}{|c|}{ Urobilinogen, $\mathrm{mg} / \mathrm{dl}$} & \multirow{3}{*}{ Normally } \\
\hline January (start) & Normally & Normally & \\
\hline May & Normally & Normally & \\
\hline
\end{tabular}




\begin{tabular}{|c|c|c|c|}
\hline December (final) & Normally & Normally & \\
\hline \multicolumn{3}{|c|}{ Ketones, mg/dl } & \multirow{4}{*}{ Negative } \\
\hline January (start) & Negative & Negative & \\
\hline May & Negative & Negative & \\
\hline December (final) & Negative & Negative & \\
\hline \multicolumn{3}{|c|}{ Glucose, mg/dl } & \multirow{4}{*}{ Negative } \\
\hline January (start) & Negative & Negative & \\
\hline May & Negative & Negative & \\
\hline December (final) & Negative & Negative & \\
\hline \multicolumn{3}{|c|}{ Protein, mg/dl } & \multirow{4}{*}{ Negative } \\
\hline January (start) & 30 & 30 & \\
\hline May & 30 & 30 & \\
\hline December (final) & 15 & 30 & \\
\hline \multicolumn{3}{|c|}{ Blood, ery/ $\mu \mathrm{l}$} & \multirow{4}{*}{ Negative } \\
\hline January (start) & Negative & Negative & \\
\hline May & Negative & Negative & \\
\hline December (final) & Negative & Negative & \\
\hline \multicolumn{3}{|c|}{$\mathrm{pH}$} & \multirow{4}{*}{$5-7$} \\
\hline January (start) & 7 & 7 & \\
\hline May & 7 & 7 & \\
\hline December (final) & $5-7$ & $6-8$ & \\
\hline \multicolumn{3}{|c|}{ Nitrite, $\mathrm{mg} / \mathrm{kg}$} & \multirow{4}{*}{ Negative } \\
\hline January (start) & Negative & Negative & \\
\hline May & Negative & Negative & \\
\hline December (final) & Negative & Negative & \\
\hline \multicolumn{3}{|c|}{ Leukocytes, leu/ $\mu \mathrm{l}$} & \multirow{4}{*}{ Negative } \\
\hline January (start) & Negative & Negative & \\
\hline May & Negative & Negative & \\
\hline December (final) & Negative & Negative & \\
\hline \multicolumn{3}{|c|}{ Specific gravity } & \multirow{4}{*}{$1.015-1.025$} \\
\hline January (start) & $1.010-1.025$ & $1.010-1.025$ & \\
\hline May & $1.015-1.025$ & $1.015-1.025$ & \\
\hline December (final) & $1.015-1.025$ & $1.015-1.025$ & \\
\hline
\end{tabular}

Note: $\mathrm{E}=$ experimental group $(80 \mathrm{~g} \mathrm{SC} / \mathrm{had} /$ day); C = control group. Limits according to laboratory standards-DocUReader-LabStrip urinalysis

\section{CONCLUSIONS}

Milk yield was influenced by Saccharomyces cerevisiae addition in the diet of the experimental group compared to the control group after a 12-month period. There was an improvement in the milk protein and milk lactose at the end of the experiment, while the fat content was not influenced by the yeast addition. The haematological and biochemical/urine parameters studied were not influenced by the Saccharomyces cerevisiae addition in the diet of dairy cows. However, for alkaline phosphatase, differences at the end of the study have been observed. The use of Saccharomyces cerevisiae as an alternative source of protein, vitamins and minerals in the dairy cows' diets could represent an effective means to optimize animal productivity. In addition to the positive effects on productive performances, fresh yeast is a cheap raw material, helping to reduce feed costs in dairy farms.

Funding Source: This study was supported by Project No. 4469/2018 "Research on the development and implementation of new dairy cows feeding technology using natural protein and mineral additives".

\section{REFERENCES}

1. Bakr HA, Hassan MS, Giadinis ND, Panousis N, OstojiC AndriC D, Abd El-Tawab MM, Bojkovski J. Effect of Saccharomyces cerevisiae supplementation on health and performance of dairy cows during transition and early lactation period. Biotechnol Anim Husb. 2015; 31(3):349-364. 
2. Bitencourt LL, Silva JRM, Oliveira BML, Dias Junior GS, Lopes F, Siecola Junior S, Zacaroni OF, Pereira MN. Diet digestibility and performance of dairy cows supplemented with live yeast. Sci Agric. 2011; 68(3):301-307, https://doi.org/10.1590/S0103-90162011000300005.

3. Burlacu Gh, Cavache A, Burlacu R. The productive potential of fodder and their use. Bucharest: Ceres Publishing House. c2002.

4. Carberry CA, Kenny DA, Han S, McCabe MS, Waters SM. Effect of phenotypic residual feed intake and dietary forage content on the rumen microbial community of beef cattle. Appl Environ Microbiol. 2012; 78:4949-4958.

5. Chaucheyras-Durand F, Walker ND, Bach A. Effects of active dry yeasts on the rumen microbial ecosystem: past, present and future. Anim Feed Sci Technol. 2008; 145:5-26.

6. Cooke KM, Bernard JK, West JW. Performance of lactating dairy cows fed whole cottonseed coated with gelatinized starch plus urea or yeast culture. J Dairy Sci. 2007; 90:360-364.

7. Dehority BA. Numbers, factors affecting the population and distribution of rumen bacteria. In: Dehority BA, editor. Rumen Microbiology. Nottingham: Nottingham University Press; c2003. p. 265-294.

8. Directive 2010/63/EU regarding handling and protection of animals used for scientific purposes, OJEU L 276/33 IA.

9. El-Ghani AA. Influence of diet supplementation with yeast culture (Saccharomyces cerevisiae) on performance of Zaraibi goats. Small Rum Res. 2004; 52:223-229.

10. Guedes CM, Goncalves D, Rodrigues MAM, Dias-Da-Silva A. Effects of Saccharomyces cerevisiae yeast on ruminal fermentation and fiber degradation of maize silages in cows. Anim Feed Sci Technol. 2008; 145:27-40.

11. Hristov A, Varga G, Cassidy T, Long M, Heyler K, Karnati S, Corl B, Hovde C, Yoon I. Effect of Saccharomyces cerevisiae fermentation product on ruminal fermentation and nutrient utilization in dairy cows. J Dairy Sci. 2010; 93(2):682-692.

12. Law no. 43/2014 regarding handling and protection of animals used for scientific purposes, OM no.326/Part I.

13. Maamouri O, Selmi H, M’hamdi N. Effects of yeast (Saccharomyces cerevisiae) feed supplement on milk production and its composition in Tunisian Holstein Friesian cows. Sci Agric Bohem. 2014; 45(3):170-174.

14. Mosoni P, Chaucheyras-Durand F, Bera-Maillet C, Forano E. Quantification by real-time PCR of cellulolytic bacteria in the rumen of sheep after supplementation of a forage diet with readily fermentable carbohydrates: effect of a yeast additive. J Appl Microbiol. 2007; 103:2676-2685.

15. Parvu G, Costea M, Pirvu M, Nicolae B. Treaty by animal nutrition. Bucharest: Coral Sanivet Publishing. c2003.

16. Poppy GD, Rabiee AR, Lean IJ, Sanchez WK, Dorton KL, Morley PS. A meta-analysis of the effects of feeding yeast culture produced by anaerobic fermentation of Saccharomyces cerevisiae on milk production of lactating dairy cows. J Dairy Sci. 2012; 95:6027-6041, doi: 10.3168/jds.2012-5577.

17. Santra A, Karim S. Rumen manipulation to improve animal productivity. Asian-Aust J Anim Sci. 2003; 16:748763.

18. Shakira G, Atiya A, Ahmed I. Effects of dietary supplementation of yeast (Saccharomyces cerevisiae) culture on growth performance, blood parameters, nutrient digestibility and fecal flora of dairy heifers. J Anim Plant Sci. $2015 ; 25: 53-59$.

19. Sniffen CJ, Chaucheyras-Durand F, Ondarza MB, Donaldson G. Predicting the impact of a live yeast strain on rumen kinetics and ration formulation. In: Proceedings of the South West Nutrition and Management Conference, Phoenix: USA. c2007. p. 53-59.

20. Stoica I, Stoica L. The basics of animal nutrition and feeding. Bucharest: Coral Sanivet Publishing House. c2001. p. 151-161.

21. Uyeno Y, Shigemori S, Shimosato T. Effect of probiotics/prebiotics on cattle health and productivity. Microbes Environ. 2015; 30(2):126-132. doi:10.1264/jsme2.ME14176.

22. Zanetti G, Paparella S, Trinchieri A, Prezioso D, Rocco F, Naber KG. Infections and urolithiasis: current clinical evidence in prophylaxis and antibiotic therapy. Arch Ital Urol Androl. 2008; 80(1):5-12.

23. Zhu W, Wei Z, Xu N, Fan Yang F, Yoon I, Chung Y, Liu J, Wang J. Effects of Saccharomyces cerevisiae fermentation products on performance and rumen fermentation and microbiota in dairy cows fed a diet containing low quality forage. J Anim Sci Biotechnol. 2017; 8:36, https://doi.org/10.1186/s40104-017-0167-3. 